\title{
Glycemic Index and Glycemic Load of Selected Staples Based on Rice, Yam and Cassava Commonly Consumed in Côte d'Ivoire
}

\author{
Camille Adam Kouamé $^{1,2,3 *}$, Nestor Kouakou Kouassi ${ }^{1}$, Aïssatou Coulibaly ${ }^{1}$, Denis Yao N'dri ${ }^{1}$, \\ Georges Gnomblesson Tiahou ${ }^{4}$, Lokrou Adrien ${ }^{5}$, Georges N'guessan Amani ${ }^{2}$
}

${ }^{1}$ Laboratory of Food Biochemistry and Tropical Products Technology, Nutrition and Food Safety Section, Department of Food Science and Technology, Nangui Abrogoua University, Abidjan, Côte d'Ivoire; ${ }^{2}$ Laboratory of Food Biochemistry and Tropical Products Technology, Biochemistry Section, Department of Food Science and Technology, Nangui Abrogoua University, Abidjan, Côte d'Ivoire; ${ }^{3}$ Laboratory of Nutrition and Food Safety, Department of Food Science and Technology, Nangui Abrogoua University, Abidjan, Côte d'Ivoire; ${ }^{4}$ Laboratory of Medical Biochemical, Faculty of Medical Sciences, Felix Houphouët-Boigny University, Abidjan, Côte d'Ivoire; ${ }^{5}$ Endocrinology and Metabolic Diseases Department, Centre Hospitalier Universitaire (CHU) de Yopougon, Abidjan, Côte d'Ivoire.

Email: *kadamcamille@gmail.com

Received November $4^{\text {th }}, 2013$; revised December $4^{\text {th }}, 2013$; accepted December $11^{\text {th }}, 2013$

Copyright (C) 2014 Camille Adam Kouamé et al. This is an open access article distributed under the Creative Commons Attribution License, which permits unrestricted use, distribution, and reproduction in any medium, provided the original work is properly cited. In accordance of the Creative Commons Attribution License all Copyrights (C) 2014 are reserved for SCIRP and the owner of the intellectual property Camille Adam Kouamé et al. All Copyright (c) 2014 are guarded by law and by SCIRP as a guardian.

\section{ABSTRACT}

Integrating information on the glycemic index (GI) and the glycemic load (GL) of diet is limited in Côte d'Ivoire because of the lack of data. Thus, this study was undertaking for the local management and prevention of diabetes mellitus and its complications based on nutritional data (GI and GL values). The study included ten healthy subjects with 7 males, 3 females ( $28 \pm 2$ years on average age and $20.5 \pm 1.7$ on average BMI). Participants tested three different meals with equal carbohydrate load (50 g). Blood samples were obtained at 0, 15, 30, 45, 60, 90 and $120 \mathrm{~min}$ before and after consumption for glucose levels determination. GIs were determined using a standard method with glucose as reference food and data were used for GLs calculating. Data showed that GIs value of pounded yam with eggplant sauce and cassava paste with granulates palm nut sauce were high ranging to 94 to 86 respectively while rice with groundnut sauce, have a low GI $(G I=45)$. Nevertheless, the GLs of the all the test foods are high with the values of 47,43 and 23 (g) for pounded yam with eggplant sauce, cassava paste with granulates palm nut sauce and rice with groundnut sauce respectively. According to GIs and GLs data, the three test foods must be consumed moderately in a diet. So, it is important to associate GL data to GI data of Ivorian traditional foods for the management and the prevention of diabetes mellitus in Côte d'Ivoire and in others countries sharing the same food tradition.

\section{KEYWORDS}

Diabetes Mellitus; Management; Prevention; Glycemic Index; Glycemic Load; Ivorian Traditional Foods

\section{Introduction}

In contradiction with long-standing conventional wisdom, that it is a rich country's disease, diabetes mellitus is increasingly a major in developing countries, especially in sub-Saharan Africa [1]. Côte d'Ivoire is placed as the first biggest diabetics' country in the sub-Saharan Africa

*Corresponding author. such as Nigeria and Senegal, with prevalence amounting to $4.93 \%$ of the population [2]. In this area, diabetes mellitus has been associated with a high prevalence of complications [3]. The special epidemiological features of medically diagnosed diabetes in Côte d'Ivoire included age of occurrence and higher morbidity in young male patients from 30 to 49 years, likely links with socio-cultural environmental factors and existence of two diabetes 
subgroups [4]. Data showed that dietary management is important in achieving better glycemic control to reduce the risk of diabetic complications and to prolong the life expectancy [5]. And, according to Kalergis et al. [6], nutrition is of the utmost importance in intensive diabetes management and has been described as the cornerstone of care. Thus, a major focus of the nutritional management of diabetes is the improvement of glycemic control by balancing food intake with endogenous and/or exogenous insulin levels [6]. Therefore, one way to maintain this balance is glycemic index (GI) [7] and glycemic load (GL) [8]. There is currently much scientific and popular interest in the role of low GI foods in the management of weight and metabolic disease risk [9]. However, both observational and intervention studies are hampered by a lack of knowledge of GI and GL values for many Western African traditional foods [10]. Most of the published GI and GL data do not represent meals commonly consumed in Côte d'Ivoire. Thus, the aim of this study was to measure the GI and the GL of a number of key "staple" carbohydrate-rich foods in Ivorian diet for nutritional guidelines.

\section{Material and Methods}

\subsection{Subjects}

Ten healthy subjects were recruited to participate in the study. Subjects were physically examined by a medical doctor on the basis of the following criteria: age 18 to 55 years; body mass index 20 to $25 \mathrm{~kg} / \mathrm{m}^{2}$ (WHO criteria); fasting blood glucose 4 to $7 \mathrm{mmol} / \mathrm{L}$. Exclusion criteria were as follows: active gastrointestinal or metabolic disease (e.g. celiac disease), first-degree family history of diabetes, and a current course of medication. Pregnant and lactating women were also excluded. Subjects were staff and students from Nangui Abrogoua University. Ethical approval for the study was obtained from Medical Sciences Faculty of Abidjan. Subjects were given full details of the study protocol and the opportunity to ask questions. All subjects gave written informed consent prior to participation. All anthropometric measurements were made in the fasting state. Height was recorded to the nearest centimeter using a stadiometer (Seca Ltd, UK), with subjects standing erect and without shoes. Body weight was recorded to the nearest $0.1 \mathrm{~kg}$, with subjects wearing light clothing and no shoes. BMI was calculated using the standard formula: weight $(\mathrm{kg}) /$ height $\left(\mathrm{m}^{2}\right)$.

\subsection{Test Foods and Preparation}

Three starchy foods usually consumed with sauces by the Ivorian population were tested: pounded yam (foutou d'igname) with eggplant sauce (sauce gnagnan), Cassava paste (placali) with granulates palm nut sauce (sauce graine) and rice (riz blanc) with groundnut sauce (sauce arachide), were tested in the study. The ingredients of the test foods were purchased from Market of Port-Bouët in District of Abidjan (Côte d'Ivoire). A sample description and the preparation methods used, according to common practices in Côte d'Ivoire are described in Table 1.

\subsection{Chemical Analysis}

Laboratory of Food Biochemistry and Tropical Products Technology of Nangui Abrogoua University analyzed the chemical composition of the study meals. Each part of the meal (starchy food + sauce) were analyzed for moisture, fat, protein and total dietary fibre (gravimetric method) using standard AOAC methods [11]. Available carbohydrate was calculated by difference. Samples were analysed based on fresh matter. Moisture was determined by oven drying at $105^{\circ} \mathrm{C}$ for $20 \mathrm{~h}$. The protein content was estimated (nitrogen $\times 6.25$ ) from quantitative analysis of nitrogen by using the Kjeldahl method. The fat was measured gravimetrically by extraction in diethyl ether and petroleum ether after acid hydrolysis. These analyses were carried out in triplicate.

\subsection{Study Design}

The protocol used was adapted from that described by Wolever et al. [12] and is in line with procedures recommended by the FAO/WHO [13]. Subjects tested the meals once each and the reference food (50 g glucose in $250 \mathrm{ml}$ water, Glucose pur anhydre, COOPER, Place Lucien Anvert) three times in random order on separate days. $50 \mathrm{~g}$ of available carbohydrate for each test food sample was calculated from the results of the proximate analysis and the measured portion of the food was served to the subjects. The total amount served of each meal was adjusted to reach this level of carbohydrate. On the day prior to a test, subjects were asked to restrict their intake of alcohol and caffeine-containing drinks and to restrict their participation in intense physical activity (e.g. long periods at the gym, excessive swimming, running and aerobics). Subjects were also told not to eat or drink after $21 \mathrm{~h}$ the night before a test, although water was allowed, in moderation. The day of the test, subjects were studied in the morning after a $12 \mathrm{~h}$ overnight fast. After a fasting blood sample, subjects consumed the test meals in the laboratory in a randomized order at 1 - 2 week intervals. They were instructed to consume all the food served in a period of $15 \mathrm{~min}$. All test meals and the reference food was served with $150 \mathrm{ml}$ water. Further blood samples were taken at 15, 30, 45, 60, 90 and 120 min after starting to eat. Subjects remained sedentary during each session. Blood was obtained by finger-prick using the Glu- 
Table 1. Processing and food preparation for the study.

\begin{tabular}{|c|c|c|c|}
\hline Meals & $\begin{array}{l}\text { Ingredient content and } \\
\text { agricultural form }\end{array}$ & $\begin{array}{l}\text { Amount } \\
\text { of foods }\end{array}$ & Preparation and cooking methods \\
\hline \multirow{5}{*}{$\begin{array}{l}\text { Pounded } \\
\text { yam with } \\
\text { eggplant } \\
\text { sauce }\end{array}$} & $\begin{array}{c}\text { Pounded yam } \\
\text { Yam } \\
\text { (Dioscorea cayenensis-rotundata) } \\
\text { variety Kponan. }\end{array}$ & 1000 g & $\begin{array}{l}\text { Pounded yam “foutou d'igname” } \\
\text { - Peel and cut out in pieces the yam tubers } \\
\text { - Cook the pieces of yams in water (1 L) during } 20 \text { min with sharp fire until their } \\
\text { softening } \\
\text { - } \quad \text { Let drain in a strainer during } 1 \mathrm{~min} \text {. } \\
\text { Crush in a mortar, the cooked yams during } 15 \text { min and progressively of crushing, } \\
\text { the cooking water is added there until obtaining a consistent and elastic paste. Balls } \\
\text { are rolled manually starting from this paste and are been useful with sauce dishes. }\end{array}$ \\
\hline & $\begin{array}{l}\text { Eggplant sauce (Solanum indicum L) } \\
\text { Fresh Okra, (Hibiscus esculentus) }\end{array}$ & $200 \mathrm{~g}$ & \multirow{4}{*}{$\begin{array}{l}\text { Eggplant sauce "sauce gnagnan" } \\
\text { - Setting with cooking of the ingredients (except onions) with sharp fire in a pot } \\
\text { containing } 1 \mathrm{~L} \text { water during } 20 \text { min. } \\
\text { - Withdraw then let drain. } \\
\text { - Crush eggplant and peppers in a strainer using one "eight of wood" in order to } \\
\text { - } \text { separate peas from their skin. } \\
\text { - } \quad \text { Add the cooked okra to it, salt is added there and the onion previously cut is } \\
\text { - handed out in medium of cooking. } \\
\text { Add a shelf and half seasoning MAGGI TABLETTE } ® \text { at the end of the cooking } \\
\text { and let the whole of it cook up. }\end{array}$} \\
\hline & Fresh peppers (Capsicum frutescens) & $25 \mathrm{~g}$ & \\
\hline & Onion (Allium серa) & & \\
\hline & Seasoning “MAGGI TABLETTE®” & $10 \mathrm{~g}$ & \\
\hline \multirow{6}{*}{$\begin{array}{l}\text { Cassava } \\
\text { paste with } \\
\text { granulates } \\
\text { palm nut } \\
\text { sauce }\end{array}$} & $\begin{array}{c}\text { Cassava paste } \\
\text { Cassava paste fermented } \\
\text { (Manihot esculenta Crantz) }\end{array}$ & $1000 \mathrm{~g}$ & $\begin{array}{l}\text { Cassava paste "placali" } \\
\text { - } \quad \text { spread the paste of manioc in } 2.5 \mathrm{~L} \text { water in a pot then to leave at } \\
\text { slightly tilted rest in position during } 1 \mathrm{~h} \\
\text { - } \quad \text { Eliminate the floating and filter the base using a strainer. } \\
\text { - } \quad \text { Milk obtained (filtrate) is put at cooking with sharp fire. Stir up constantly using a } \\
\text { wood spatula until obtaining a translucent and very consistent paste during } 25 \text { min. }\end{array}$ \\
\hline & $\begin{array}{l}\text { Granulates palm nut sauce } \\
\text { African Oil Palm } \\
\text { (Elaeis guineensis) }\end{array}$ & $1500 \mathrm{~g}$ & $\begin{array}{l}\text { Granulates palm nut sauce "sauce graine” } \\
\text { - Cook with sharp fire, in } 1 \mathrm{~L} \text { of water, seeds of palm until their softening } \\
\text { (during } 35 \text { min) with draw seeds then let drain. }\end{array}$ \\
\hline & $\begin{array}{l}\text { fresh peppers } \\
\text { (Capsicum frutescens) }\end{array}$ & $25 \mathrm{~g}$ & $\begin{array}{l}\text { - In a mortar, crush seeds in order to entirely separate the flesh from the cores. } \\
\text { - Add seven litres of water }(7 \mathrm{~L}) \text {, mix up the whole then press in order to eliminate } \\
\text { fiber and the cores. }\end{array}$ \\
\hline & Onion (Allium сера) & $70 \mathrm{~g}$ & $\begin{array}{l}\text { - } \quad \text { Filter the juice obtained three by collecting the filtrate in a pan. } \\
\text { - } \quad \text { Carry the juice to cooking during } 3 \text { hours' time approximately to average fire. }\end{array}$ \\
\hline & salt & $10 \mathrm{~g}$ & $\begin{array}{l}\text { While boiling, add to it fresh peppers, salt and onions previously cut out } \\
\text { - At the end of cooking, add a shelf and half seasoning MAGGI TABLETTE® and }\end{array}$ \\
\hline & $\begin{array}{l}\text { Seasoning } \\
\text { “MAGGI TABLETTE®” }\end{array}$ & $10 \mathrm{~g}$ & $\begin{array}{l}\text { let cook up. Cooking continues until obtaining a consistent sauce with presence of } \\
\text { red oil on the surface of the sauce. }\end{array}$ \\
\hline \multirow{7}{*}{$\begin{array}{l}\text { Rice with } \\
\text { groundnut } \\
\text { sauce }\end{array}$} & $\begin{array}{l}\text { Cooked rice } \\
\text { Twice broken rice Oncle Sam® } \\
(\text { Oryza spp) }\end{array}$ & $1000 \mathrm{~g}$ & $\begin{array}{l}\text { Cooked rice "riz blanc" } \\
\text { - Salt one litre ( } 1 \mathrm{~L} \text { ) of water and carry to boiling in a pot during two minutes. } \\
\text { - Wash rice with running water then let drain carefully during two minutes. } \\
\text { - Add rice in the boiling water and stir up with two turns. Leave the whole to cooking } \\
\text { with sharp fire until rice is quite tender and absorbed all water } \\
\text { (approximately during } 15 \text { min). }\end{array}$ \\
\hline & $\begin{array}{l}\text { Groundnut sauce } \\
\text { groundnut (Arachis hypogeae) }\end{array}$ & $1500 \mathrm{~g}$ & \multirow{6}{*}{$\begin{array}{l}\text { Groundnut sauce "Sauce arachide" } \\
\text { - Roast groundnut seeds in a soft fire pot until the skin of groundnut seeds falls apart } \\
\text { easily. } \\
\text { - Then grind groundnut seeds removed from their skin in a mortar and crush on a } \\
\text { broad stone made for this purpose and using an empty bottle for obtaining a paste. } \\
\text { - Spread two hundred gram of this paste in 1L, water. The whole is put at fire and } \\
\text { supplemented with } 3 \mathrm{~L} \text { water. Each } 5 \text { min, add the following ingredients: salt, fresh } \\
\text { peppers, concentrated tomato paste and onions cut out beforehand in section. At the } \\
\text { end of the cooking, add the shelf of seasoning MAGGI TABLETTE®. Duration of } \\
\text { cooking } 2 \mathrm{~h} \text { at the conclusion, an oil film appears on the surface of sauce. }\end{array}$} \\
\hline & fresh peppers (Capsicum frutescens) & $15 \mathrm{~g}$ & \\
\hline & $\begin{array}{l}\text { Concentrated tomato paste } \\
\text { (Lycopersicon esculentum) }\end{array}$ & $30 \mathrm{~g}$ & \\
\hline & Onion (Allium сера) & $100 \mathrm{~g}$ & \\
\hline & salt & $10 \mathrm{~g}$ & \\
\hline & Seasoning “MAGGI TABLETTE” & $10 \mathrm{~g}$ & \\
\hline
\end{tabular}


colet 2 multipatient lancing system (Bayer Health Care). Blood glucose was measured using an automatic analyser (Ascensia Contours; Bayer Health Care).

\subsection{Calculation of Glycemic Index and Glycemic Load}

The GI was calculated using the method described by FAO/WHO [13] as the area under the blood glucose response curve of a $50 \mathrm{~g}$ carbohydrate portion of the test food expressed as a percent of the response to the same amount of carbohydrate from a standard food taken by the same subject. The area under the blood glucose response curve was calculated geometrically by applying the trapezoid rule [14]. When a blood glucose value falls below the baseline, only the area above the fasting level is included. The GI of each meal tested was taken as the mean ( \pm s.e.m.) for the whole group. GI values were classified as high (70 - 100), intermediate (55 - 69), or low $(<55)$ [15]. Glycemic Load for each food was determined by the method of Salmeron et al. [16]. In each individual glycemic load was calculated bay taking the percentage of the food's carbohydrate content in a typical serving and multiplying it by its glycemic index value [17]. GL values were classified as low $(\leq 10)$, medium $(>10$ to $<20)$ or high $(\geq 20)[18]$.

\subsection{Statistical Analysis}

Statistically significant differences between measurement parameters and samples were verified with one-way analysis of variance using the Statistical Product and Service Solutions Software (SPSS version 17.0, Chicago, USA). The Tukey's honesty significant differences (HSD) multiple range tests used to determine the differences between group means at the $95.0 \%$ confidence level.

\section{Results}

\subsection{Proximate Composition of Test Meals}

The macronutrient composition of the test meals is presented in Table 2. Proximate composition showed that the fiber $(11.9 \pm 0.3 \mathrm{~g})$ and fat $(32.3 \pm 0.0 \mathrm{~g})$ content of cassava paste with granulates palm nut sauce were very much highest than those of pounded yam with eggplant sauce and rice with groundnut sauce. However, rice with groundnut sauce has the highest protein $(15.8 \pm 0.1 \mathrm{~g})$ content of all three test foods.

\subsection{Descriptive Characteristics}

Ten healthy subjects were recruited are 7 men and 3 women with $20.5 \pm 1.7 \mathrm{~kg} \cdot \mathrm{m}^{-2}$ on average body mass index (BMI) and $28.5 \pm 2.1$ years on average age. Normal readings of the standard glucose used in the clinical chemistry analyser ranged from 4.0 - $6.4 \mathrm{mmol} / \mathrm{L}$ glucose. The initial blood glucose obtained from the normal subjects for all test foods did not exceed $6.0 \mathrm{mmol} / \mathrm{L}$ glucose (Table 3). No significant differences were observed between subjects for the fasting blood glucose $(p>0.05)$.

\subsection{Blood Glucose Response, GI and GL of Test Meals}

The mean blood glucose responses up to 120 min following ingestion of the three meals and glucose are shown in Figures 1, 2 and 3. Fasting blood glucose levels did not differ before the treatments. The blood glucose levels for both the pounded yam with eggplant sauce and rice with groundnut sauce were significantly lower at 15 min than the glucose $(p<0.05)$. At $30,45,60 \mathrm{~min}$, only the rice with groundnut sauce was significantly lower than the glucose $(p<0.05)$. The reference food (glucose), pounded yam with eggplant sauce and cassava paste with granulates palm nut sauce showed significantly higher glucose responses compared to those of rice with ground-nut sauce (Area Under the Curve, AUC: mean \pm s.e.m.; $\mathrm{mmol} \times \mathrm{min} / \mathrm{L}: 83.8 \pm 26.3$ vs. $186.5 \pm 60.5 ; 174.5 \pm$ 56.0 and $159.4 \pm 50.9$ for rice with groundnut sauce, glucose, pounded yam with eggplant sauce and cassava paste with granulates palm nut sauce; $p<0.05$, respectively, see Table 4). Although, pounded yam with eggplant sauce and cassava paste with granulates palm nut sauce blood glucose dynamics was increased, they did

Table 2. Nutrient composition of foods tested, per $\mathbf{5 0}$ g available carbohydrate portion.

\begin{tabular}{|c|c|c|c|c|c|c|c|c|}
\hline & $\begin{array}{c}\text { Weight (g) } \\
\text { serving ingested }\end{array}$ & Moisture (g) & Protein (g) & Fat (g) & Ash (g) & $\begin{array}{l}\text { Avialable } \\
\text { CHO* (g) }^{*}\end{array}$ & $\begin{array}{l}\text { Dietary } \\
\text { fibre (g) }\end{array}$ & $\begin{array}{l}\text { Energy } \\
\text { (kcal) }\end{array}$ \\
\hline Pounded yam with eggplant sauce & $391.0 \pm 0.3^{\mathrm{b}}$ & $317.8 \pm 0.3^{\mathrm{b}}$ & $8.2 \pm 0.0^{\mathrm{b}}$ & $1.8 \pm 0.0^{c}$ & $3.0 \pm 0.0^{\mathrm{b}}$ & 50.0 & $10.2 \pm 0.0^{b}$ & $290.2 \pm 0.4^{\mathrm{c}}$ \\
\hline $\begin{array}{c}\text { Cassava paste with granulates } \\
\text { palm nut sauce }\end{array}$ & $499.9 \pm 2.2^{\mathrm{a}}$ & $396 \pm 1.7^{\mathrm{a}}$ & $5.9 \pm 0.2^{c}$ & $32.3 \pm 0.0^{\mathrm{a}}$ & $3.7 \pm 0.2^{\mathrm{a}}$ & 50.0 & $11.9 \pm 0.3^{\mathrm{a}}$ & $562.5 \pm 1.2^{\mathrm{a}}$ \\
\hline Rice with groundnut sauce & $335.4 \pm 0.8^{\mathrm{c}}$ & $242.6 \pm 0.4^{c}$ & $15.8 \pm 0.1^{\mathrm{a}}$ & $22.8 \pm 0.1^{\mathrm{b}}$ & $2.3 \pm 0.2^{\mathrm{c}}$ & 50.0 & $1.9 \pm 0.0^{c}$ & $475.2 \pm 1.4^{\mathrm{b}}$ \\
\hline
\end{tabular}

a,b,c The values of the same column are significantly different with the threshold from $5 \%$; CHO, carbohydrate. ${ }^{*}$ Available carbohydrate values are calculated as follows: 100 - (moisture + protein + fat + total dietary fibre + ash); AOAC Analysis [11]). 
Table 3. Descriptive characteristics of study participants at study entry*.

\begin{tabular}{ccc}
\hline Parameter & Values & Range \\
\hline Gender (male/female) & $7 / 3$ & - \\
Age (years) & $28 \pm 2$ & $26-33$ \\
Weight (kg) & $60.4 \pm 4.8$ & $54-68$ \\
Height (m) & $1.7 \pm 0.0$ & $1.6-1.8$ \\
BMI (kg·m $\left.{ }^{-2}\right)$ & $20.5 \pm 1.7$ & $18.8-24.4$ \\
Fasting blood glucose baseline $(\mathbf{m m o l} / \mathbf{L})$ & $5.5 \pm 0.2$ & $5.2-5.9$ \\
\hline
\end{tabular}

${ }^{*} \mathrm{n}=10$.

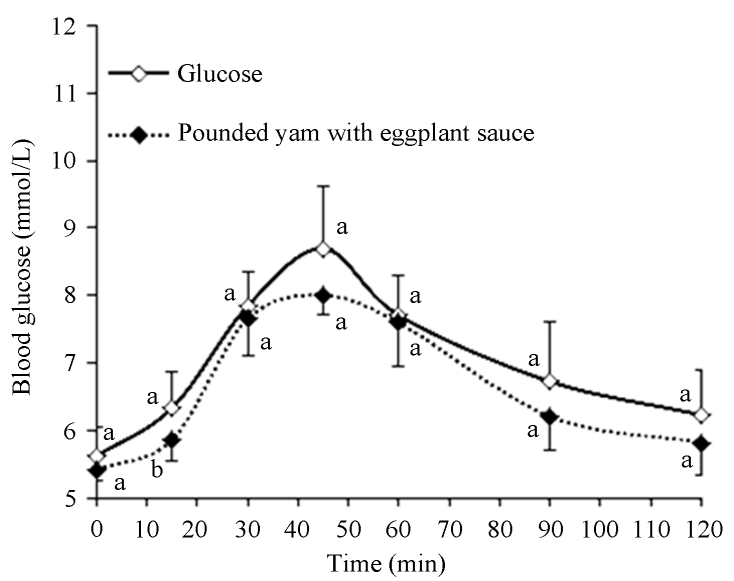

Figure 1. Glycemic profile (mmol/L) for $120 \mathrm{~min}$ after consumption of glucose $(\neg)$ and pounded yam with eggplant sauce $(\cdots \cdots)$ tested in normal subjects $(n=10)$. Points at the same time interval and bars with different letters are significantly different $(p<0.05)$, data are mean \pm s.e.m.

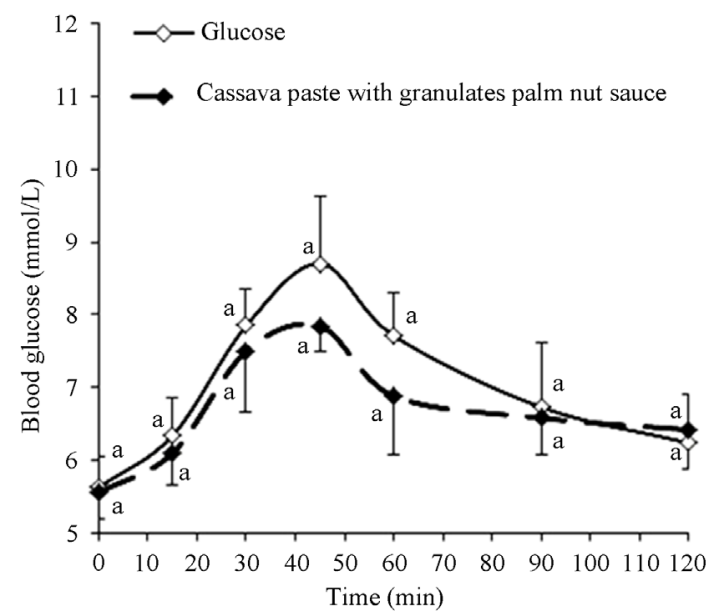

Figure 2. Glycemic profile (mmol/L) for $120 \mathrm{~min}$ after consumption of glucose $(-\sim)$ and cassava paste with granulates palm nut sauce $(\rightarrow)$ tested in normal subjects $(n=10)$. Points at the same time interval and bars with different letters are significantly different $(p<0.05)$, data are mean \pm s.e.m.

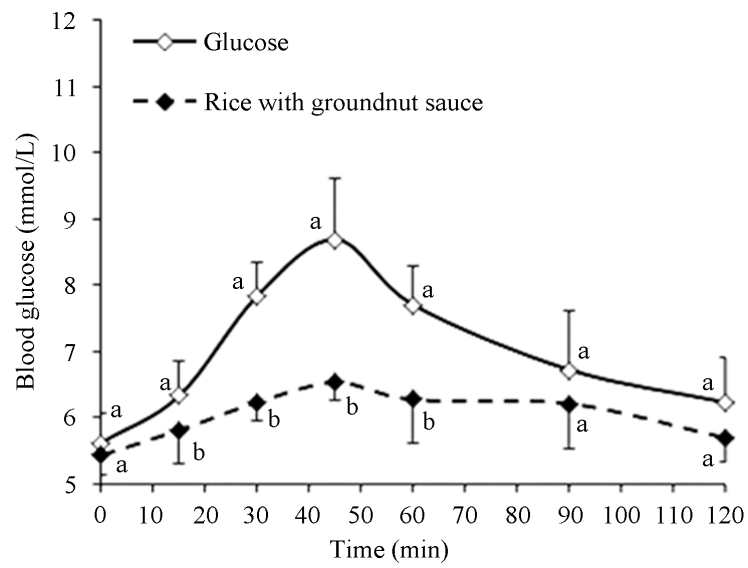

Figure 3. Glycemic profile (mmol/L) for $120 \mathrm{~min}$ after consumption of glucose $(-\diamond)$ and rice with groundnut sauce $(-\bullet)$ tested in normal subjects $(n=10)$. Points at the same time interval with different letters are significantly different $(p<0.05)$, data are mean \pm s.e.m.

not differ significantly from reference food $(p<0.05)$. GI data of the pounded yam with eggplant sauce, cassava paste with granulates palm nut sauce and rice with groundnut sauce were significantly different $(p<0.05)$ with $94 \pm 4,86 \pm 1$ and $45 \pm 3$ respectively (Figure 2). The GLs (mean \pm s.e.m.; g) were $46.9 \pm 1.9$; $42.8 \pm 0.7$ and $22.6 \pm 1.5$ for the pounded yam with eggplant sauce, cassava paste with granulates palm nut sauce and rice with groundnut sauce respectively (Table 4). All test meals have a GL significantly different $(p<0.05)$.

\section{Discussion}

According to the official classification of GI [17], data showed that rice with groundnut sauce presented a favourable glycemic response, ranking as foods with a low GI $(\mathrm{GI}=45)$.

The GIs of pounded yam with eggplant sauce and cassava paste with granulates palm nut sauce were high and ranging to 94 and 86 respectively. The American Dietetic Association (ADA) reviewed the evidence of glycemic index as a nutrition therapy intervention for diabetics and acknowledged that low glycemic index foods may reduce postprandial blood glucose levels and asserted that there is sufficient.evidence of long term benefit to recommend using low glycemic index diets as a primary strategy in meal planning [19]. On this base, the rice with groundnut sauce produces a lower increase of the plasma glucose concentration, as a result of slower rates of gastric emptying and digestion of carbohydrate in the intestinal lumen [12]. Data provides evidence that rice with groundnut sauce with low GI could be an ideal food for diabetic diets. So, rice with groundnut sauce releases gradually from glucose, which avoids an important "glycemic peak" and reduce the risk of diabetes mellitus. That appears on 
Table 4. AUC, glycemic index/load and classification of tests foods.

\begin{tabular}{cccccccc}
\hline Test foods & $\begin{array}{c}\text { AUC-glucose } \\
(\mathbf{m m o l} \times \mathbf{m i n} / \mathbf{L})\end{array}$ & $\begin{array}{c}\text { AUC-test foods } \\
(\mathbf{m m o l} \times \mathbf{m i n} / \mathbf{L})\end{array}$ & GI & \multicolumn{2}{c}{$\begin{array}{c}\text { GI } \\
\text { Classification }\end{array}$} & $\begin{array}{c}\text { GL } \\
\text { (per serving) }\end{array}$ & $\begin{array}{c}\text { GL } \\
\text { Classification }\end{array}$ \\
\hline Pounded yam with eggplant sauce & $186.5 \pm 60.5 \mathrm{a}$ & $174.5 \pm 56.0^{\mathrm{a}}$ & $94 \pm 4^{\mathrm{b}}$ & High & $47 \pm 2^{\mathrm{b}}$ & High \\
Cassava paste with granulates palm nut sauce & $186.5 \pm 60.5 \mathrm{a}$ & $159.4 \pm 50.9^{\mathrm{a}}$ & $86 \pm 1^{\mathrm{c}}$ & High & $43 \pm 1^{\mathrm{c}}$ & High & High \\
Rice with groundnut sauce & $186.5 \pm 60.5 \mathrm{a}$ & $83.8 \pm 26.3^{\mathrm{b}}$ & $45 \pm 3^{\mathrm{d}}$ & Low & $23 \pm 1^{\mathrm{d}}$ & $\mathrm{H}$ \\
\hline
\end{tabular}

Value are expressed as mean \pm s.e.m $(n=10$ determinations $)$. AUC = Area under the plasma glucose curves; GI = Glycemic Index; GL = Glycemic Load; Means in the same column sharing the same letter superscript not differ significantly $(p<0.05)$.

the weakness of its hyperglycemic peak $(6.5 \pm 0.3$ $\mathrm{mmol} / \mathrm{L}$ at $45 \mathrm{~min}$, Figure 3 Indeed, more gastric emptying is slowed down, more the waves of hypergly cemias postprandial are weak and absorption of carbohydrates set out again in time [20]. The GI value of rice with groundnut sauce is in the same order as those mentioned by Nientao et al. [21] which has showed low GI of rice $(\mathrm{GI}=46)$. Besides, the values of the GI can vary according to the process of meals confection. For this purpose, Omoregie \& Osagie [10] showed that the high GI (GI = 95) of food containing rice "Tuwo Shinkafa" is due to the rice which was crushed and cooked with water in order to obtain a pasta product. The glycemic response of pounded yam with eggplant sauce and cassava paste with granulates palm nut sauce showed that both foods raise blood glucose levels quickly and high. There are quickly converted into glucose, quickly digested and absorbed and in most cases a quick rise in insulin [22]. Hyperinsulinemia may also, over time, lead to insulin resistance via increases in the blood glucose concentration [7] and thereby increase the risk of type 2 diabetes and obesity [23]. GI data of these foods are similar to those of the "Tapioca", (food based on cassava, GI = 81) [24] and lower than "N" gbô (food based on boiled yam, GI $=53$ - 70) [5]. The difference on GIs of the three test meals was probably due to their biochemical composition. Indeed, GI of mixed meals is reduced by coingestion of protein, fiber or fat. The presence of large amounts of protein or fat may significantly reduce the glycemic response by increasing insulin secretion and slowing gastric emptying [25]. On this basis, the association of levels of fat, protein and fiber in foods provide contents of 20.2 g, $40.5 \mathrm{~g}$ and $50.1 \mathrm{~g}$ for the pounded yam with eggplant sauce, rice with groundnut sauce and cassava paste with granulates palm nut sauce respectively. In principle, the GI classification of foods should be: GI of pounded yam with eggplant sauce > GI of rice with groundnut sauce > GI of cassava paste with granulates palm nut sauce. This is not the case for the cassava paste with granulates palm nut sauce which have a high proportion of macronutrients, and GI high $(G I=86)$. This significant increase in the GI could be notably due to the carbohydrate fraction including physico-chemical characteristics of its starch.
Indeed, cassava paste with granulates palm nut sauce is the one that has the highest water content $(396 \pm 1.7 \%)$ among food (Table 2). As a result, the starch is gelatinized most. This high starch gelatinization has certainly inhibited the action of macronutrients and to increase the GI of the dish. Starch is more digestible, digestion is more rapid and high GI [5]. According to Mendosa [26], for a better control of glycemic response on diabetes mellitus management and its prevention, GI data must be associated to GL data. In this study, it's appear that the GLs of foods were 47, 43 and 23 for pounded yam with eggplant sauce; cassava paste with granulates palm nut sauce and rice with groundnut sauce respectively. According to the official classification of GL [26], all the test meals have high GL (GL > 20 g). So, their consumption should be limited because they could increase the insulin response. Indeed, beyond the GL day labourer of $80 \mathrm{~g}$, food can involve an important insulin secretion. And, more GL, the higher the food contains glycemic carbohydrate [26]. Therefore, rice groundnut sauce (GL = 23 ) is the food that has the highest low glycemic carbohydrate foods among the three tests. Thus, although all three tests foods can negatively influence health, rice with groundnut sauce would be the least aggressive to the body.

\section{Conclusion}

This study has provided GI and GL values for three common staple carbohydrate-rich foods in the Ivorian diet. The pounded yam with eggplant sauce and cassava paste with granulates palm nut sauce, which has high GI, and high GL are hyperglycemic foods these two (2) foods must be eaten in very small quantities. Rice with groundnut sauce is a low-GI food but its GL remains high. This meal, which seems to be advised to the diabetics diet must be consumed moderately. These data will serve as nutritional guidelines for the prevention and the management of diabetes mellitus in Côte d'Ivoire.

\section{Acknowledgements}

This work was financed within the Agricultural Productivity Program in West Africa (PPAAO/WAAPP 1B.) 
Don IDA N ${ }^{\circ} 6260$ CI et Don $N^{\circ} \mathrm{TF} 098014$ CI by FIRCA (Fonds Interprofessionnel pour la Recherche et le Conseil Agricoles). In addition, the authors wish to thank Dr Abodo Jacko (Endocrinology and Diabetology Department; Universitary and Hospital Center of Yopougon, Abidjan) for his technical support and volunteers for their collaboration. We are grateful also for the helpful assistance of Yapi D. A., Gbakayoro J. B., Kroufie A., Degbeu C., Voho E. Alida Sandrine and Yapo G. Bruno.

\section{REFERENCES}

[1] S. B. Gning, M. Thiam, F. Fall, K. Ba-Fall, P. S. Mbaye and L. Foucarde, "Le Diabète sucré en Afrique SubSaharienne: Aspect Epidémiologique, Difficultés de Prise en Charge,"Médecine Tropicale, Vol. 67, No. 6, 2007, pp. 607-611.

[2] "Atlas du Diabète de la Fédération Internationale du Diabète,” Cinquième Edition, Mise à Jour, 2012. www.idf.org/diabetesatlas

[3] A. J. C. Azoh, A. Lokrou, D. Koffi, A. M. Dem-Niacadié, J. Abodo, M. D. Laubhouet, A. Derbé, M. Sanogo, F. Amani, A. Doumbia and F. Kouassi, "Diabète et Syndrome Métabolique en côte d'Ivoire: À Propos d'une Série de 85 cas,” Diabetes \& Metabolism, Vol. 33, No. Spe1, 2007, p. 54.

[4] A. S. S. Oga, J. A. Tebi, V. K. Adouemi, K. A. Malan, A. Kouadio and A. Lokrou, "Le Diabète Diagnostiqué en Côte d'Ivoire: Des Particularités Epidémiologiques,"Médecine Tropicale, Vol. 66, 2006, pp. 241-246.

[5] K. N. Kouassi, G. G. Tiahou, F. R. J. Abodo, M. CamaraCisse and N. G. Amani, "Influence of the Variety and Cooking Method on Glycemic Index of Yam," Pakistan Journal of Nutrition, Vol. 8, No. 7, 2009, pp. 993-999. http://dx.doi.org/10.3923/pjn.2009.993.999

[6] M. Kalergis, E. De Grandpre and C. Andersons, "The Role of the Glycemic Index in the Prevention and Management of Diabetes: A Review and Discussion," Canadian Journal of Diabetes, Vol. 29, No. 1, 2005, pp. 27-38.

[7] M. Sleeth, A. Psichas and G. Frost, "Weight Gain and Insulin Sensitivity: A Role for the Glycaemic Index and Dietary Fibre?” British Journal of Nutrition, Vol. 109, No. 9, 2012, pp. 1539-1541. http://dx.doi.org/10.1017/S0007114512005016

[8] K. Marsh and J. Brand-Miller, "Glycemic Index, Obesity, and Chronic Disease," American Journal of Lifestyle Medicine, Vol. 2, No. 2, 2008, pp. 142-150.

[9] L. M. Aston, J. M. Gambell, D. M. Lee, S. P. Bryant and S. A. Jebb, "Determination of the Glycaemic Index of Various Staple Carbohydrate-Rich Foods in the UK Diet," European Journal of Clinical Nutrition, Vol. 62, No. 2, 2008, pp. 279-285. http://dx.doi.org/10.1038/sj.ejcn.1602723

[10] E. S. Omoregie and A. U. Osagie, "Glycemic Indices and Glycemic Load of Some Nigerian Foods,” Pakistan Journal of Nutrition, Vol. 7, No. 5, 2008, pp. 710-716.

[11] AOAC, “Official Methods of Analysis," 13th Edition,
Association of Official Analytical Chemists, Washington DC, 1983, pp. 755-800.

[12] T. M. S. Wolever, "The Glycaemic Index: A Physiological Classification of Dietary Carbohydrate,” Biddles Ltd, King’s Lynn Ed, UK, 2006, p. 227.

[13] FAO/WHO, “Carbohydrates in Human Nutrition,” FAO Food and Nutrition Paper 66, Report of an FAO/WHO Expert Consultation on Carbohydrates, 14-18 April 1997, Food and Nutrition Paper, FAO, Rome, 1998, 140 p.

[14] F. Brouns, I. Bjorck, K. N. Frayn, A. L. Gibbs, V. Lang, G. Slama and T. M. S. Wolever, "Glycaemic Index Methodology,” Nutrition Research Reviews, Vol. 18, No. 1, 2005, pp. $145-171$.

http://dx.doi.org/10.1079/NRR2005100

[15] J. Brand-Miller, T. M. S. Wolever, K. Foster-Powell and S. Colagiuri, "The New Glucose Revolution: The Authoritative Guide to the Glycemic Index,” Marlowe and Company, New York, 2003.

[16] J. Salmeron, J. E. Manson, M. J. Stampfer, G. A. Colditz, A. L. Wing and W. C. Willett, "Dietary Fiber, Glycaemic Load, and Risk of Non-Insulin-Dependent Diabetes Mellitus in Women,” JAMA, Vol. 277, No. 6, 1997, pp. 472477. http://dx.doi.org/10.1001/jama.1997.03540300040031

[17] S. F. Atkinson, K. Foster-Powell and J. C. Brand-Miller, "International Tables of Glycemic Index and Glycemic Load Values: 2008,” Diabetes Care, Vol. 31, No. 12, 2008, pp. 2281-2283. http://dx.doi.org/10.2337/dc08-1239

[18] B. J. Venn and T. J. Green, "Glycemic Index and Glycemic Load: Measurement Issues and Their Effect on DietDisease Relationships,” European Journal of Clinical Nutrition, Vol. 61, Suppl. 1, 2007, pp. S122-S131. http://dx.doi.org/10.1038/sj.ejcn.1602942

[19] American Diabetes Association, "Nutrition Recommendation and Interventions for Diabetes: A Position Statement of ADA,” Diabetes Care, Vol. 31, 2008, pp S561S578.

[20] A. Grimaldi, “Guide Pratique du Diabète,” Éd. Spéciale, Paris, 1998, pp. 39-49.

[21] A. Nientao, S. Besançon and D. Béran, "Etude de l’Index Glycémique des Principales Céréales Consommées au Mali: Mil, riz, fonio, Sorgho et Maïs par Rapport au Pain Blanc (Aliment de Référence)," Rapport final d'activité, Phase 1 Axe 1-Activité 3. Projet SDM (Santé diabète Mali), ONG Appui au Développement, Santé Diabète Mali (SDM), 2006, 25 p.

[22] D. S. Ludwig, “The Glycemic Index: Physiological Mechanisms Relating to Obesity, Diabetes, and Cardiovascular Disease,” JAMA, Vol. 287, No. 18, 2002, pp. 24142423. http://dx.doi.org/10.1001/jama.287.18.2414

[23] J. C. Brand-Miller, S. H. A. Holt, D. B. Pawlak and J. McMillan, "Glycemic Index and Obesity," American Journal of Clinical Nutrition, Vol. 76, No. 1, 2002, pp. 281S285S.

[24] T. M. S. Wolever, L. Katzman-Relle, A. L. Jenkins, V. Vuksan, R. B. Josse and D. J. Jenkins, “Glycaemic Index of 102 Complex Carbohydrate Foods in Patients with 
Diabetes,” Nutrition Research, Vol. 14, No. 5, 1994, pp. 651-669.

http://dx.doi.org/10.1016/S0271-5317(05)80201-5

[25] K. Y. Lok, R. Chan, D. Chan, L. Li, G. Leung, J. Woo, H. J. Lightowler and C. J. K. Henry, "Glycaemic Index and Glycaemic Load Values of a Selection of Popular Foods
Consumed in Hong Kong,” British Journal of Nutrition, Vol. 103, No. 4, 2010, pp. 556-560. http://dx.doi.org/10.1017/S0007114509992042

[26] Mendosa R, "Revised International Table of Glycemic Index (GI) and Glycemic Load (GL) Values-2008,” 2008, 127 p. http://www.mendosa.com/gilists.htm

\section{Abbreviations and Acronyms}

ADA: American Dietetic Association;

AOAC: Official Methods of Analysis;

AUC: Area Under the Curve;

BMI: Body Mass Index;
CHO: Carbohydrate;

FAO: Food and Agriculture Organization;

GI: Glycemic Index;

GL: Glycemic Load;

WHO: World Health Organization. 